\title{
E-Preferences of MSMEs to Zakah or Tax in Covid-19 Period
}

\author{
Rossje V Suryaputri ${ }^{1}$, Fitri Kurniawati ${ }^{2}$ \\ \{rossjevi@trisakti.ac.id ${ }^{1}$ \} \\ Master of Accounting, Faculty of Economics and Business, Universitas Trisakti ${ }^{1}$ \\ Faculty of Economics and Business, Universitas Trisakti ${ }^{2}$
}

\begin{abstract}
The pandemic caused by Covid 19 today has made it difficult for MSMEs to survive in their business fields. However, as good citizens, Moslem entrepreneurs find it obligatory to pay taxes, and at the same time to also pay zakah, as part of the pillars of Islam to be fulfilled. In response to these conditions, this research is aimed to obtain the preferences of MSME entrepreneurs towards taxes with Zakah in the Greater Jakarta areas, by using a qualitative approach with ANP (Analytic Network Process) through BOCR (Benefit, Opportunity, Cost, and Risk). This study obtained data from nine expert sources consisting of four categories, i.e., MSME, scholars, practitioners from the Department of Taxes, and Amil Zakah. The result of this research is the perception that MSMEs prefer to choose to pay their taxes $(0.597)$ than Zakah (0.224). From the BOCR approach, the highest is Benefit (0.262), then Risk (0.250), Cost (0.226), and Opportunity (0.220). The highest benefits are increasing credibility (0.400), receiving incentives from the government (0.288), and obtaining equity from banks $(0.237)$. The value risk is customers loss (0.362), punishment (0.273), and loss of credibility (0.269). The cost values are preferences for paying taxes from Zakah (0.396), deduction in business profit (0.336), and citizens' obligations (0.204). The Opportunity value is the ease to get a business license (0.394), to manage the administration of public services (0.284), and to help set up business finances (0.234).
\end{abstract}

Keywords: Benefit Opportunity Cost Risk (BOCR); Zakah; Tax

\section{Introduction}

Covid-19 pandemic that swept the world since the beginning of 2020 has affected the world economy significantly. The weakening of the global economy also affected domestic economic conditions. Micro, Small, and Medium Enterprises (MSMEs) are at the forefront of experiencing the impacts of the economic recession caused by the pandemic. The implementation of Large-Scale Social Restriction and Micro-Scale Social Restriction affects MSME operations. According to the Result Analysis of the Covid-19 Impact Survey to the business people conducted by BPS in 2020 [1], 84.20\% of MSMEs experienced a decrease in income. During the Large-Scale Social Restriction, 78.35\% of MSMEs experienced declining 
demand because customers were also affected by the pandemic. Meanwhile, $62.21 \%$ of MSMEs face financial problems related to employees and operational activities.

MSMEs play essential roles in the Indonesian economy. MSMEs contribute to labor employment, Gross Domestic Product (GDP) growth, social safety nets, exports increase, and investment opportunity. MSMEs contributed to the national economy (GDP) by $61.1 \%$, while the rest came from large businesses, amounted to $0.01 \%$ of all business players. The MSME sector is dominated by micro-entrepreneurs where $98.68 \%$ is reflected in their ability to employ as many as labors up to $89 \%$. The government as a policymaker has made various efforts to reduce the impact of the pandemic, for instance issuing The Ministry of Finance (MoF) Regulation No.44/PMK.03/2020 (PMK-44) on Tax Incentives for Taxpayers affected by Covid-19. Other related incentives, such as Income Tax (PPh) Article 21, borne by government, exemption on imported goods (Income Tax (PPh) Article 22), reduction of installment rates on Income Tax $(\mathrm{PPh})$ Article 25, and accelerated restitution [2].

The decision to extend the tax incentives was made to help taxpayers affected by Covid19. Referring to The Ministry of Finance (MoF) Regulation Number 9/PMK.03/2021 on Tax Incentives for Taxpayers Affected by the Covid- 19 Pandemic, the final Income Tax incentives for micro, small, and medium enterprises (MSMEs) are also borne by the government. Meanwhile, the zakah sector increased by $46 \%$ during the pandemic. During the January to June 2020 period, the total funds collected at Baznas reached IDR240.39 billion. This amount is higher than the same period in 2019, which was around IDR156.83 billion. The distribution of zakah also increased during the January-June 2020 period to $129.82 \%$. It encourages an increase in the number of recipients of zakah by 87.42 percent compared to 2019. This condition is an indication that public awareness to pay zakah is getting higher. In Surah Al Baqarah verse 257, only those who earn and get the wealth by legal can pay zakah. Zakah can be paid monthly or collected in advance for one year as $2.5 \%$ of total income in each month. Zakah will be distributed to eight groups entitled to receive zakah, including the indigent, the poor, amil zakah, converts, slaves, gharim, fi sabilillah, and ibn sabil.

On the other hand, the community is faced double obligation on paying zakah and taxes. Therefore, the government makes regulations that are expected to be a solution in this problem. In 2010 the government issued Indonesian Government Regulation Number 60 on zakah or religious contributions that are obligatory can deduct from gross income. In 2011, the Directorate General of Taxes issued regulation Number PER-33/PJ/2011 on the establishment of entities or institutions founded or legalized by the government as zakah recipient or religious donations, which are obligatory and can be deducted from gross income - followed by Law no. 23 of 2011 on Zakah Management Article 22 stating that zakah paid by muzakki to BAZNAS or LAZ is deducted from taxable income. Article 23 paragraph (1) states that BAZNAS or LAZ are obliged to provide proof of zakah payment to each muzakki; (2) the proof of payment as referred to paragraph (1) is used as a deduction of taxable income. The proof of deposit can be used as a deduction of gross income in the annual tax return. However, there are not many people who use these facilities. The position of zakah, which is only a tax deduction is considered to have no significant impact on paid tax value.

The purpose of this study was to determine the preferences of MSME in fulfilling their obligations as citizens by paying taxes, and as Moslem by paying zakah. This research has novelty compared to previous research. The previous study only tested the effect of the zakah incentive variable as a tax credit, along with the impact of other variables on the participation rate of muzakki and taxpayers using the SEM method. This study was to compare the preferences of MSME in paying zakah or taxes using the Analytic Network 
Process (ANP) method. The former research and framework of this study can be seen respectively in Tabel.1 and Figure 1.

Table 1. Summary of the previous researches

\begin{tabular}{|c|c|c|c|}
\hline No & Research Title & Researchers & Research Results \\
\hline 1 & $\begin{array}{l}\text { Prospects of Zakah } \\
\text { as Tax Credit in a } \\
\text { New rormal } \\
\text { COVID-19 } \\
(2021)\end{array}$ & $\begin{array}{l}\text { Any } \\
\text { Setianingrum, } \\
\text { Nurul Huda, } \\
\text { dan Perdana } \\
\text { Wahyu } \\
\text { Santosa }\end{array}$ & $\begin{array}{l}\text { Regulatory variables, zakah incentives as tax credits, } \\
\text { technology-based services, socialization, and } \\
\text { promotions significantly affect the preferences of } \\
\text { muzakki and taxpayers. At the same time, the } \\
\text { regulatory variables, zakah incentives as tax credits, } \\
\text { socialization, and promotion, have a significant } \\
\text { impact on muzakki and taxpayer } \\
\text { participation. Meanwhile, service and technology } \\
\text { preferences in this study did not significantly affect } \\
\text { the participation of muzakki and taxpayers [3]. }\end{array}$ \\
\hline 2 & $\begin{array}{lr}\text { Kebijakan } & \text { Pajak } \\
\text { Indonesia } & \\
\text { Menanggapi } & \text { Krisis } \\
\text { Covid-19: Manfaat } \\
\text { bagi Wajib Pajak } \\
(2020)\end{array}$ & $\begin{array}{l}\text { Aswin } \\
\text { Padyanoor }\end{array}$ & $\begin{array}{l}\text { The government issued a policy to help } \\
\text { taxpayers affected by Covid-19. Taxpayers receive } \\
\text { the benefits of reducing rates to the exemption from } \\
\text { income tax so that the economy can rise and become } \\
\text { stable [4]. }\end{array}$ \\
\hline 3 & $\begin{array}{l}\text { The Selection of } \\
\text { Zakah Fundraising } \\
\text { Activities of Zakah } \\
\text { Management } \\
\text { Organizations } \\
\text { in East Java Using } \\
\text { Analytic Network } \\
\text { Process (2020) }\end{array}$ & $\begin{array}{l}\text { Noven Lukito } \\
\text { Hadi Saputro, } \\
\text { Raditya } \\
\text { Sukmana }\end{array}$ & $\begin{array}{l}\text { Direct fundraising, with a priority value of } 37.90 \% \\
\text { (W=significant), is the most dominant alternative in } \\
\text { East Java. Then, digital fundraising }(25.11 \%, \mathrm{~W}= \\
\text { significant) is the second alternative, and indirect } \\
\text { fundraising (17.12\%, W = significant) is the third } \\
\text { alternative [5]. }\end{array}$ \\
\hline 4 & $\begin{array}{lr}\text { Strategi Peningkatan } \\
\text { Target Wajib Pajak } \\
\text { Bagi } & \text { UMKM } \\
\text { Dengan } & \text { Metode } \\
\text { Analytic } & \text { Network } \\
\text { Process } & \text { (ANP) } \\
(2020) & \end{array}$ & $\begin{array}{l}\text { Imelda Dian } \\
\text { Rahmawati, } \\
\text { Muhammad } \\
\text { Nasih }\end{array}$ & $\begin{array}{l}\text { Using the Network Process Analysis (ANP) method, } \\
\text { the priority strategy for increasing income from the } \\
\text { MSME sector was obtained. The strategy to improve } \\
\text { tax services for MSME taxpayers is in the first } \\
\text { rank. Tax services for MSME taxpayers include the } \\
\text { convenience of tax reporting, tax paying, and access } \\
\text { to information about taxes [6]. }\end{array}$ \\
\hline 5 & $\begin{array}{l}\text { Zakah Compliance } \\
\text { Behavior among } \\
\text { Entrepreneurs: } \\
\text { Economic Factors } \\
\text { Approach (2020) }\end{array}$ & $\begin{array}{l}\text { Saeed Awadh } \\
\text { Bin-Nashwan, } \\
\text { Hijattulah } \\
\text { Abdul-Jabbar, } \\
\text { Saliza Abdul } \\
\text { Aziz, Alhassan } \\
\text { Haladu }\end{array}$ & $\begin{array}{l}\text { The suitability of the approach to economic factors in } \\
\text { the context of Zakah Compliance (ZC) in developing } \\
\text { countries. In particular, this study shows that the } \\
\text { complexity of the zakah law has a significantly } \\
\text { negative effect on the ZC of entrepreneurs. The study } \\
\text { also found a significant positive relationship between } \\
\text { religiosity and ZC among the study sample, while the } \\
\text { study revealed that law enforcement does not affect } \\
\text { compliance behavior [7]. }\end{array}$ \\
\hline 6 & $\begin{array}{l}\text { A socio-economic } \\
\text { model of } \\
\text { Zakah compliance } \\
(2020)\end{array}$ & $\begin{array}{l}\text { Saeed Awadh } \\
\text { Bin-Nashwan, } \\
\text { Hijattulah } \\
\text { Abdul-Jabbar, } \\
\text { Saliza Abdul } \\
\text { Aziz, K. K. } \\
\text { Kuperan } \\
\text { Viswanathan }\end{array}$ & $\begin{array}{l}\text { All variables included in the compliance model were } \\
\text { statistically significant, except law } \\
\text { enforcement. Entrepreneurs' zakah compliance is } \\
\text { significantly influenced by the fairness of the zakah } \\
\text { system, zakah morals, and the influence of those } \\
\text { closest to them [8]. }\end{array}$ \\
\hline
\end{tabular}




\begin{tabular}{|c|c|c|c|}
\hline No & Research Title & Researchers & Research Results \\
\hline 7 & $\begin{array}{l}\text { Zakah as a Tax } \\
\text { Credit for } \\
\text { Indonesian } \\
\text { Revenue (2019) }\end{array}$ & $\begin{array}{l}\text { Any } \\
\text { Setianingrum, } \\
\text { Penny Rahmah } \\
\text { Fadhilah, Aam } \\
\text { Slamet } \\
\text { Rusydiana }\end{array}$ & $\begin{array}{l}\text { The analytical tool used is ANP (Analytic Network } \\
\text { Process). Based on the research results, the first rank } \\
\text { is zakah as a tax credit with a weight of } 0.469 \text {. The } \\
\text { second alternative is zakah as a deduction from } \\
\text { taxable income with a weight of } 0.385 \text {. The third or } \\
\text { last alternative is zakah and taxes, which do not } \\
\text { directly relate to the weight of } 0.146 \text { [9]. }\end{array}$ \\
\hline 8 & 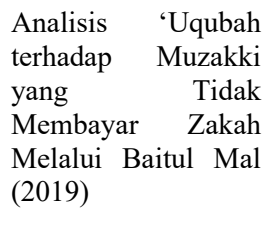 & Nurdin & $\begin{array}{l}\text { The penalty for muzakki who do not pay zakah } \\
\text { because they deny the obligation of zakah will be } \\
\text { punished by hadd practice (battled or a dive alms } \\
\text { killed). 'Uqubah for muzakki reluctant to give } \\
\text { for miserly attitude, then zakah is taken by force and } \\
\text { accompanied ta'zir form of a good half of his } \\
\text { possessions, and imprisoned when necessary [10]. }\end{array}$ \\
\hline 9 & $\begin{array}{l}\text { Zakah as Tax Credit } \\
\text { for Harmonize Fiscal } \\
\text { Setting in Indonesia } \\
(2018)\end{array}$ & $\begin{array}{l}\text { Any } \\
\text { Setianingrum, } \\
\text { Suhirman } \\
\text { Madjid, } \\
\text { Masagus } \\
\text { Asaari }\end{array}$ & $\begin{array}{l}\text { The results of the integration analysis show that the } \\
\text { tax credit from zakah can increase revenue in the } \\
\text { zakah and tax sector, compared to zakah only as a } \\
\text { cost or as a deduction from taxable income. As a } \\
\text { controlling tax payment, zakah can recruit muzakki to } \\
\text { be included in the group who pays zakah and taxes } \\
\text { without causing a double burden for those who pay } \\
\text { zakah. This policy is in line with PSAK 101, where } \\
\text { zakah does not include in the income statement [11]. }\end{array}$ \\
\hline 10 & $\begin{array}{lr}\text { Menggali } & \text { Realitas } \\
\text { Kepatuhan } & \text { Wajib } \\
\text { Pajak } & \text { Pemilik } \\
\text { UMKM (2017) }\end{array}$ & $\begin{array}{l}\text { Sura Klaudia, } \\
\text { Dewi Rimba } \\
\text { Riwayanti, dan } \\
\text { Aminatunnisa }\end{array}$ & $\begin{array}{l}\text { Taxpayers who do not comply to pay } \\
\text { taxes because they think taxes can be substituted } \\
\text { by charity. MSMEs do not have the confidence to } \\
\text { pay taxes due to the lack of } \\
\text { socialization, the government's indecisiveness in } \\
\text { implementing tax regulations, and they do not } \\
\text { directly feel the positive impact of paying taxes [12]. }\end{array}$ \\
\hline
\end{tabular}

\section{Methodology}

\subsection{Analytical Network Process}

Analytic Network Process is an analytical tool used in this research. The decision-making process is carried out without making assumptions about the independence of elements from higher elements to lower elements and the independence of elements at a level [13]. The ANP questionnaire arranged in the form of a pairwise comparison between elements in the cluster to find out which of the two has a more dominant influence and how big the difference is from one side. The numerical scale of 1-9 is the definition of verbal assessment.

Table 2. Definition for Verbal Scale dan Numeric Scale

\begin{tabular}{lc}
\hline \multicolumn{1}{c}{ Definition } & Intensity of Importance \\
\hline Extreme Importance & 9 \\
For Compromises Between the Above Values & 8 \\
Very Strong and Demonstrated Importance & 7 \\
For Compromises Between the Above Values & 6 \\
Strong Importance & 5 \\
For Compromises Between the Above Values & 4 \\
\hline
\end{tabular}




\begin{tabular}{lc}
\hline \multicolumn{1}{c}{ Definition } & Intensity of Importance \\
\hline Moderate Importance & 3 \\
For Compromises Between the Above Values & 2 \\
Equal Importance & 1 \\
\hline
\end{tabular}

The foundation of ANP theory has four axioms, namely:

a. Reciprocal, this axiom states that if a PC (EA, EB) is a comparative value pair of elements $\mathrm{A}$ and $\mathrm{B}$, seen from its parent element $\mathrm{C}$, which indicates how many times more elements for $\mathrm{C}$, how many times more element for $\mathrm{A}$ has a thing possessed by the elements $\mathrm{B}$, then $\mathrm{PC}(\mathrm{EB}, \mathrm{EA})=1 / \mathrm{Pc}(\mathrm{EA}, \mathrm{EB})$.

b. Homogeneity states that the elements compared in the ANP framework structure should not be too significant to cause greater errors in determining the assessment of supporting elements that influence decisions.

c. Priority is absolute weighting using an interval scale $(0,1)$ and a measure of relative dominance.

d. The dependence condition is assumed to be an arrangement composed of components that make up the cluster.

The ANP research stages are shown in Figure 1 below:

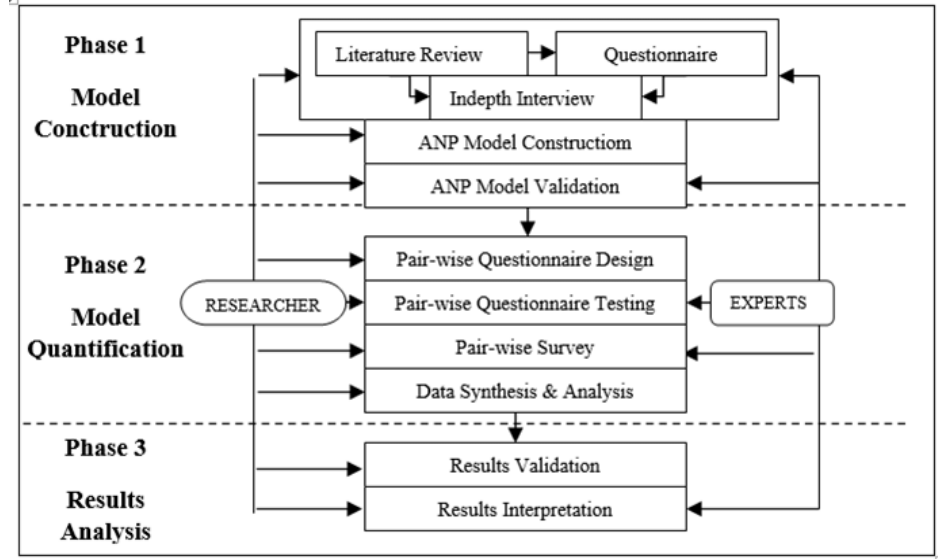

Fig. 1. Stages of ANP

\subsection{BOCR (Benefits, Opportunities, Costs, Risks)}

BOCR (Benefits, Opportunities, Costs, Risks) is one of many Analytic Network Process models. BOCR can be used to determine alternatives because it has criteria, and there are alternative solutions like other ANP models. Saaty and Vargas explain that benefits are profitable things, while costs is a non profitable thing [14]. Worries that happen due to uncertainty decision is a positive opportunity, and risk is something negative that can happen. Therefore, Benefit is a positive thing obtained in the short term. Opportunity is a benefit that is possible to gain in the future. Cost is a negative thing that will happen in the short term. Meanwhile, the risk is a loss that is likely to be experienced in the future. 


\section{Results and Discussion}

\subsection{Analysis Result}

The model construction in this study comes from various references, which are described as follows:

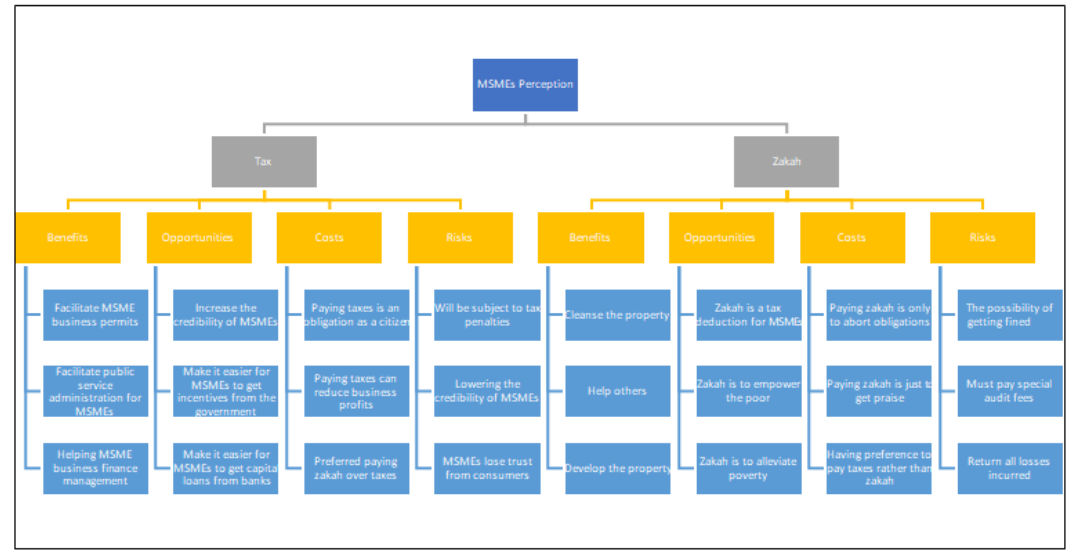

Source: Image Processed (2021)

Fig. 2. ANP Model Construction

The explanations for each variable that become clusters and sub-clusters of the model are as follows:

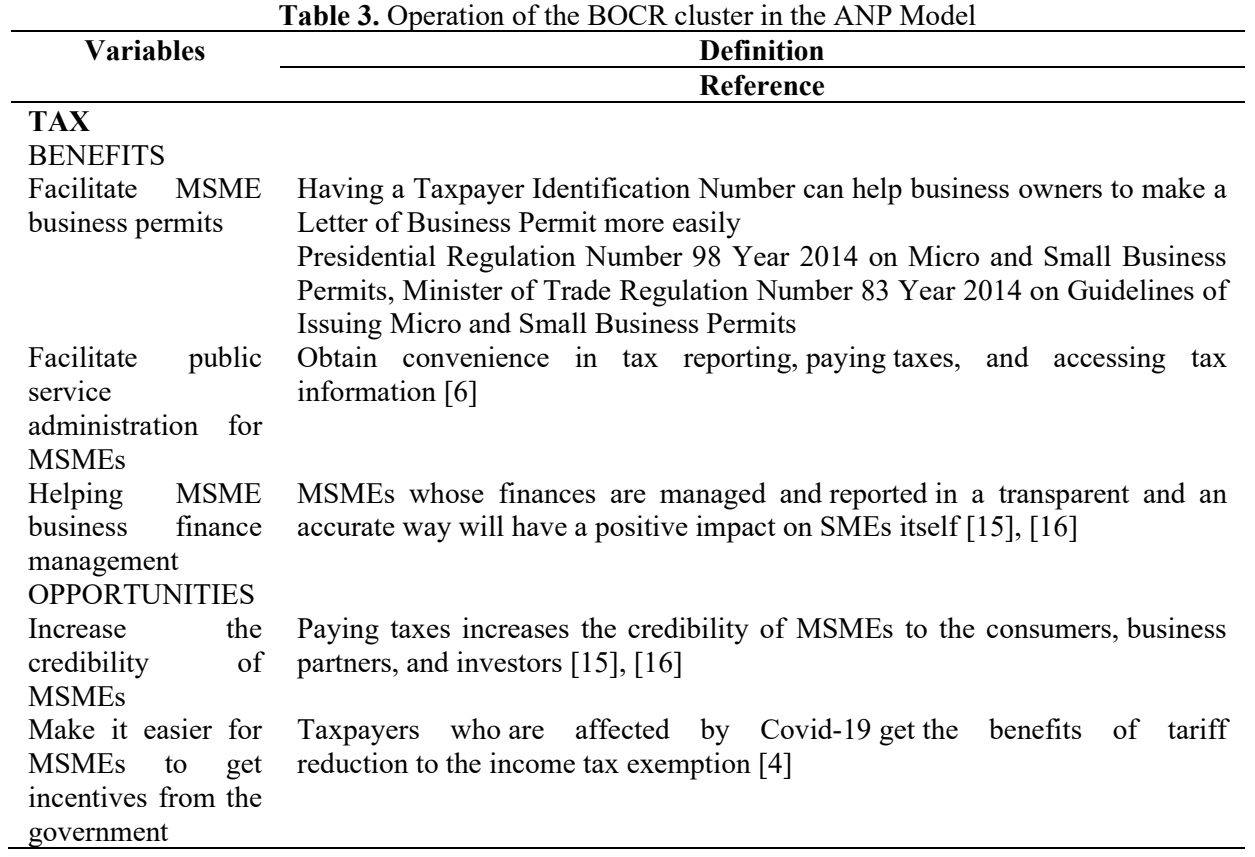




\begin{tabular}{|c|c|}
\hline Variables & Definition \\
\hline & Reference \\
\hline $\begin{array}{l}\text { Make it easier for } \\
\text { MSMEs to get } \\
\text { capital loans from } \\
\text { banks } \\
\text { COSTS }\end{array}$ & $\begin{array}{l}\text { MSMEs who are orderly paid taxes will increase their level so they are easy to } \\
\text { get loans from financial institutions [15], [16] }\end{array}$ \\
\hline $\begin{array}{l}\text { Paying taxes is an } \\
\text { obligation as a } \\
\text { citizen }\end{array}$ & $\begin{array}{l}\text { The government determined the tax rate for MSMEs which are operating in } \\
\text { Indonesia }\end{array}$ \\
\hline $\begin{array}{l}\text { Paying } \\
\text { reduce } \\
\text { profits }\end{array}$ & $\begin{array}{l}\text { Law Number 20/2008 on MSMEs Business; [16]. } \\
0.5 \text { percent final tax income is considered to be borne by SMEs because } \\
\text { its calculation is based on the total gross income without any deductions [16], } \\
\text { [17]. }\end{array}$ \\
\hline $\begin{array}{l}\text { Preferred paying } \\
\text { zakah over taxes }\end{array}$ & $\begin{array}{l}\text { Taxpayers feel that zakah can replace their tax payments. In addition, } \\
\text { taxpayers do not think they get direct benefits after paying taxes to the state, } \\
\text { so taxpayers are reluctant to pay taxes. [12], [17] }\end{array}$ \\
\hline RISKS & \\
\hline $\begin{array}{l}\text { Will be subject to } \\
\text { tax penalties }\end{array}$ & $\begin{array}{l}\text { MSMEs are obedient to paying taxes because they are afraid of severe } \\
\text { sanctions if they violate the government regulations. [16], [18] }\end{array}$ \\
\hline $\begin{array}{l}\text { Lowering the } \\
\text { credibility } \\
\text { MSMEs }\end{array}$ & $\begin{array}{l}\text { The credibility of MSMEs who do not comply with paying taxes can decrease } \\
\text { and affect MSME performance [15], [16]. }\end{array}$ \\
\hline $\begin{array}{l}\text { MSMEs lose trust } \\
\text { from consumers }\end{array}$ & $\begin{array}{l}\text { MSMEs will risk losing consumers' trust in the future if they do not comply } \\
\text { with taxes [15], [16]. }\end{array}$ \\
\hline $\begin{array}{l}\text { ZAKAH } \\
\text { BENEFITS }\end{array}$ & \\
\hline $\begin{array}{l}\text { Cleanse the } \\
\text { property }\end{array}$ & Zakah can purify the soul and show concern from the tax payers. \\
\hline & Al Qur'an Surah At-Taubah verses 35 and 103; [19]-[21] \\
\hline Help others & Zakah can reduce poverty and income gaps [22], [23]. \\
\hline $\begin{array}{l}\text { Develop the } \\
\text { property }\end{array}$ & Zakah helps double the property owned so that the payers get blessings in life. \\
\hline & $\begin{array}{l}\text { Al Qur'an Surah Ar Ruum verses 39; Al Qur'an Surah Al Baqarah verses } 276 \\
\text { [21]. }\end{array}$ \\
\hline $\begin{array}{l}\text { OPPORTUNITIES } \\
\text { Zakah is a tax } \\
\text { deduction }\end{array}$ & $\begin{array}{l}\text { Zakah paid by Muzakki (Zakah Giver) to BAZNAS or the Amil Zakah } \\
\text { Institution (LAZ) is deducted from Taxable Income }\end{array}$ \\
\hline & $\begin{array}{l}\text { Law Number } 23 \text { Article } 22 \text { Year } 2011 \text { on Management of Zakah; Director } \\
\text { General of Tax Regulation number PER-11/PJ/2018; Government Regulation } \\
\text { Number } 60 / 2010\end{array}$ \\
\hline $\begin{array}{l}\text { Zakah is to } \\
\text { empower the poor }\end{array}$ & $\begin{array}{l}\text { Zakah paid by muzakki is distributed to mustahiq to develop the business } \\
\text { owned by mustahiq. } \\
\text { Aprilianto and Widiastuti, 2021; [24] }\end{array}$ \\
\hline $\begin{array}{l}\text { Zakah is to } \\
\text { alleviate poverty } \\
\text { COSTS }\end{array}$ & Zakah is distributed to the poor to meet their daily needs [25] \\
\hline $\begin{array}{l}\text { Paying zakah is } \\
\text { only to abort } \\
\text { obligations }\end{array}$ & $\begin{array}{l}\text { Zakah is seen only as an obligation because they do not understand the } \\
\text { meaning of paying zakah [26]. }\end{array}$ \\
\hline $\begin{array}{l}\text { Paying zakah is } \\
\text { just to get praise }\end{array}$ & $\begin{array}{l}\text { People pay zakah because they expect to call benefactors after they have paid } \\
\text { zakah [26]. }\end{array}$ \\
\hline
\end{tabular}




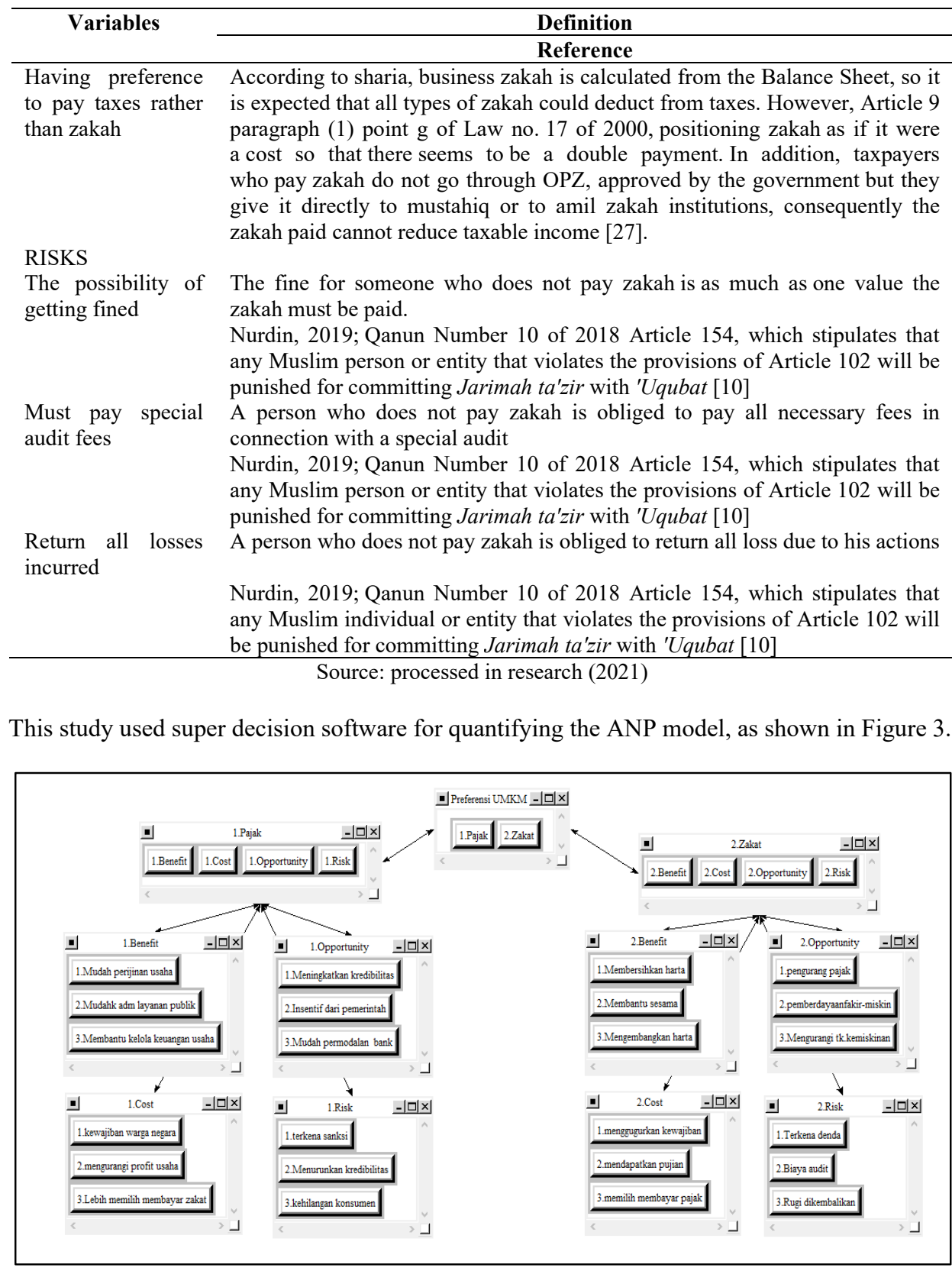

Fig. 3. ANP-BOCR Model in Superdecison Software

The framework above shows the established ANP-BOCR research model. The framework shows three BOCR control criteria for each of the Tax and Zakah variables. The 
synthesis of the model and overall priorities is based on three aspects of control criteria by combining the opinion of the respondents. Aspects of BOCR that have a more considerable normalized value are ranked higher, and vice versa.

\subsection{Discussion}

The results of the analysis of the ANP model are presented as follows:

Table 5. ANP Analysis Result

\begin{tabular}{|c|c|c|c|}
\hline \multirow[t]{2}{*}{ CATEGORY } & \multicolumn{3}{|c|}{ BENEFITS-TAX } \\
\hline & $\begin{array}{l}\text { 1. Easy business } \\
\text { licensing }\end{array}$ & $\begin{array}{l}\text { 2. Easy administration } \\
\text { of public services }\end{array}$ & $\begin{array}{l}\text { 3. Help manage } \\
\text { business finances }\end{array}$ \\
\hline MSMEs & 0,297 & 0,377 & 0,234 \\
\hline ALL & 0,394 & 0,284 & 0,234 \\
\hline
\end{tabular}

Preferences BOCR on the Benefits for MSMEs are the ease for public service administration, ease for proper business permits, and finally help to manage financial businesses. Respondents consider permits more vital because it will be challenging to get a business license; of course, it significantly influences their business. Having Taxpayer Identification Number can help business owners to make a Letter of Business Permit more easily. Presidential Regulation Number 98 Year 2014 on Micro and Small Business Permits, Minister of Trade Regulation Number 83 Year 2014 on Guidelines of Issuing Micro and Small Business Permits. In addition, it is easy to report taxes, pay taxes, and access information about taxes. It is as reflected in the research conducted [6]. Table 6.

\begin{tabular}{cccc}
\hline CATEGORY & \multicolumn{3}{c}{ OPPORTUNITIES-TAX } \\
\cline { 2 - 4 } & $\begin{array}{c}\text { 1. Increase } \\
\text { credibility }\end{array}$ & $\begin{array}{c}\text { 2. Incentives from } \\
\text { the government }\end{array}$ & $\begin{array}{c}\text { 3. Easy } \\
\text { bank capital }\end{array}$ \\
\hline MSMEs & 0,377 & 0,335 & 0,208 \\
ALL & 0,400 & 0,288 & 0,237 \\
\hline
\end{tabular}

Preferences BOCR on the Opportunities for MSMEs is Enhancing credibility. Respondents' overall preference are increasing credibility, the ease of obtaining incentives from the government, and getting bank capital. SMEs tend to assume that credibility is more important because it will increase the customer's trust, and it lasts longer. Paying taxes increases the credibility of MSMEs in the eyes of consumers, business partners, and financiers. It is following the research of Ediraras, 2010; Aliyah, 2014 [15], [16]. Table 7.

\begin{tabular}{cccc}
\hline CATEGORY & \multicolumn{3}{c}{ COSTS-TAX } \\
\cline { 2 - 4 } & 1. Obligation of a citizen & 2. Reducing business profit & 3. Prefer to pay zakah \\
\hline MSMEs & 0,263 & 0,280 & 0,311 \\
ALL & 0,204 & 0,336 & 0,396 \\
\hline
\end{tabular}

Preferences BOCR on the Costs taxes that prefer to pay zakah over taxes, reducing businesses profit, and consider paying taxes only as a citizen obligation. Respondents assume the primary obligation to pay zakah more than just pay taxes; the tax may reduce profit, and just an obligation as citizens. Respondents are reluctant to pay taxes. Taxpayers feel that zakah can replace their tax payments. Taxpayers do not think they 
get direct benefits after paying taxes to the state, so taxpayers feel reluctant to pay taxes. This opinion is supported by Klaudia, Riwayanti, and Aminatunnisa, 2017; Sari and Maradona, 2020 [12], [17]. Table 8.

\begin{tabular}{cccc}
\hline CATEGORY & \multicolumn{3}{c}{ RISKS-TAX } \\
\cline { 2 - 4 } & 1. Penalized & 2. Lowering credibility & 3. Loss of consumers \\
\hline MSMEs & 0,425 & 0,264 & 0,234 \\
ALL & 0,273 & 0,269 & 0,362 \\
\hline
\end{tabular}

Preferences BOCR on the Risks for MSMEs is to be sanctioned if they do not pay taxes. Meanwhile, respondents' preference will be punished if it does not pay taxes, reduces SMEs' credibility, and finally loses consumers' confidence. Respondents are worried that they will be subject to tax sanctions which will reduce the credibility of their business so that creditors and investors do not want to give credit and invest their capital in the business. MSMEs are obedient in paying taxes because they are afraid to be subject to severe sanctions if they violate government regulations. It is following the research of Cahyani and Noviari, 2019; Aliyah, 2014 [16], [18]. Table 9.

\begin{tabular}{cccc}
\hline CATEGORY & \multicolumn{3}{c}{ BENEFITS-ZAKAH } \\
\cline { 2 - 4 } & 1. Cleanse the property & 2. Help others & 3. Develop treasure \\
\hline MSMEs & 0,254 & 0,493 & 0,199 \\
ALL & 0,250 & 0,361 & 0,317 \\
\hline
\end{tabular}

Preferences BOCR on the Benefits of zakah, MSMEs is to help others. Overall respondents prefer charity to help others, double the property owned, and cleanse the property. SMEs prioritized more in helping others to reduce poverty and Muslim welfare is expected to be achieved with zakat. Zakah is able to alleviate poverty and the income gap. This opinion is supported by Beik, 2009; Firmansyah, 2013 [22], [23]. Table 10.

\begin{tabular}{cccc}
\hline CATEGORY & \multicolumn{3}{c}{ OPPORTUNITIES-ZAKAH } \\
\cline { 2 - 4 } & 1. Tax deduction & 2. Empowerment of the poor & 3. Reducing the poverty rate \\
\hline MSMEs & 0,208 & 0,335 & 0,377 \\
ALL & 0,247 & 0,375 & 0,290 \\
\hline
\end{tabular}

BOCR's preference on the Opportunities of zakah for MSMEs is to alleviate the poverty level. Overall, respondents pay zakah to empower the poor, alleviate poverty levels, and reduce taxes for MSMEs. Zakah is distributed to the poor to meet their daily needs. This opinion is supported by the research of Kadir, Hakim, Syam, dan Karim, 2020 [25]. Table 11.

\begin{tabular}{cccc}
\hline \multirow{2}{*}{ CATEGORY } & \multicolumn{3}{c}{ COSTS-ZAKAH } \\
\cline { 2 - 4 } & 1. abort the obligation & 2. get compliments & 3. choose to pay tax \\
\hline MSMEs & 0,309 & 0,172 & 0,445 \\
ALL & 0,377 & 0,201 & 0,330 \\
\hline
\end{tabular}

BOCR's preference on MSME Zakah Costs, is choosing to pay taxes rather than zakah. Overall, respondents pay zakah only to abort obligations, choose to pay taxes from zakah, and pay zakah only to get praise. MSMEs prefer to pay zakah to abort obligations as part of the Islamic law, where Muslims who have businesses and have reached their nishab must pay zakah. 
According to sharia, business zakah is calculated from the Balance Sheet, so it is expected that all types of zakah could deduct from taxes. However, Article 9 paragraph (1) point $g$ of Law no. 17 of 2000, positioning zakah as if it were a cost so that there seems to be a double payment. In addition, taxpayers who pay zakah do not go through OPZ, approved by the government but they give it directly to mustahiq or to amil zakah institutions, consequently the zakah paid cannot reduce taxable income. It is stated by Afriyandi, 2014 [27]. Table 12.

\begin{tabular}{cccc}
\hline CATEGORY & \multicolumn{3}{c}{ RISKS-ZAKAH } \\
& 1. Fined & 2. Audit fee & 3. Loss returned \\
\hline MSMEs & 0,208 & 0,297 & 0,425 \\
ALL & 0,351 & 0,211 & 0,340 \\
\hline
\end{tabular}

BOCR's preference on the Risks of zakah for MSMEs, is to return the losses incurred. Overall, respondents who pay zakah are worried that they will be fined, return the losses incurred, and are obliged to pay audit fees. MSMEs choose to return the losses incurred if the provisions for zakah fines apply. A person who does not pay zakah is obliged to return all losses due to his actions. Nurdin, 2019 supports this opinion; Qanun Number 10 of 2018 Article 154 stipulates that any Muslim person or entity that violates Article 102 will be punished for committing jarimah ta'zir with ' Uqubat. Table 13.

\begin{tabular}{ccccccccc}
\hline \multirow{2}{*}{ CATEGORY } & \multicolumn{4}{c}{ BOCR-TAX } & \multicolumn{4}{c}{ BOCR-ZAKAH } \\
\cline { 2 - 8 } & Benefit & Opportunity & Cost & Risk & Benefit & Opportunity & Cost & Risk \\
\hline MSMEs & 0,212 & 0,193 & $\mathbf{0 , 3 1 3}$ & 0,224 & $\mathbf{0 , 2 7 9}$ & 0,196 & 0,238 & 0,226 \\
ALL & 0,262 & 0,220 & 0,226 & 0,250 & 0,300 & 0,201 & 0,269 & 0,204 \\
\hline
\end{tabular}

The government stipulates the tax rate charged for MSMEs operating in Indonesia based on Law Number 20/2008 on MSMEs Business [16]. The final income tax of 0.5 percent is considered to be borne by SMEs because its calculation is based on the total gross income without any deductions [16], [17]. Taxpayers feel that zakah can replace their tax payments. Taxpayers also do not think they get direct benefits after paying taxes to the state, so taxpayers are reluctant to pay taxes [12], [17]. Zakah serves to purify the soul and grows goodness in those who pay zakah [19]-[21]. Zakah can alleviate poverty and the income gap [22], [23]. They feel their tax payments can substitute by paying zakah. Zakah helps double the property owned so that the payers get blessings in life (Al Qur'an Surah Ar Ruum verses 39; Al Qur'an Surah Al Baqarah verses 276) [21].

\section{Conclusions}

The current pandemic caused by Covid virus makes it difficult for MSMEs to survive in their business fields. However, as a good citizen, it is obligatory to pay taxes and carry out the obligation to pay zakah as part of the pillars of Islam for Muslim entrepreneurs. The result of this study is the perception that MSMEs prefer to pay their taxes $(0.597)$ rather than zakah (0.224). From the BOCR approach, the highest is benefit $(0.262)$, risk $(0.250)$, cost $(0.226)$, and Opportunity (0.220). The highest benefits are increasing credibility (0.400), getting incentives from the government (0.288), and quickly obtaining equity from banks (0.237). Value risks are loss of customer (0.362), penalty (0.273), and loss of credibility (0.269). Cost of value is about the preference for paying taxes from zakah (0.396), minus of business profits $(0.336)$, and citizen obligations $(0.204)$. Opportunity values are the ease of 
obtaining a business license (0.394), the ease of providing public services $(0.284)$, and managing business finance (0.234). Based on the description in the discussion, it is concluded that the preference of MSMEs is tax compared to zakah. The tax BOCR preference for MSMEs is the cost that must be paid, while the zakah BOCR is the benefit obtained from paying zakah. Suggestions for further research is to continue with further research on tax and zakah preferences by category (Academics, Director General of Tax, Amil Zakah, MSMEs).

\section{References}

[1] Badan Pusat Statistik Republik Indonesia, Analisis Hasil Survei Dampak Covid-19 Terhadap Pelaku Usaha. Jakarta: BPS RI (2020).

[2] Munandar M. H. : Analysis the effectiveness of tax relaxation due to Covid-19 pandemy on Indonesian economic defense, Lex Sci. Law Rev., vol. 4, no. 1, pp. 125133 (2020).

[3] Amamani S. A., Abba S. A., and Dandago K. I.: Zakah on employment income in muslims majority states of Nigeria: Any cause for Alarm? in Procedia Social and behavioral sciences, pp. 304-314 (2014)

[4] Padyanoor A.: Kebijakan Pajak Indonesia Menanggapi Krisis COVID-19: Manfaat bagi Wajib Pajak, E-Jurnal Akunt., vol. 30, no. 9, pp. 2216-2230 (2020).

[5] Saputro N. L. H. and Sukmana R.: Pemilihan Aktivitas Fundraising Zakat Organisasi Pengelola Zakat Di Jawa Timur Menggunakan Analytic Network Process, J. Ekon. Syariah Teor. dan Terap., vol. 7, no. 3, pp. 460-471 (2020).

[6] Rahmawati I. D. and Nasih M.: Strategi Peningkatan Target Wajib Pajak Bagi UMKM Dengan Metode Analytic Network Process (ANP), JBMP (Jurnal Bisnis, Manaj. dan Perbankan), vol. 6, no. 1, pp. 8-16 (2020).

[7] Bin-Nashwan S. A., Abdul-Jabbar H. , Aziz S. A., and Haladu A.: Zakah Compliance Behavior among Entrepreneurs: Economic Factors Approach, Int. J. Ethics Syst., vol. 36, no. 2, pp. 285-302, Jan (2020). doi: 10.1108/IJOES-09-2019-0145.

[8] Bin-Nashwan S. A. ,Abdul-Jabbar H. , Aziz S. A. , and Viswanathan K. K.: A SocioEconomic Model of Zakah Compliance, Int. J. Sociol. Soc. Policy, vol. 40, no. 3/4, pp. 304-320, Jan (2020). doi: 10.1108/IJSSP-11-2019-0240.

[9] Setianingrum A. , Fadhilah P. R. , and Rusydiana A. S.: Zakah as a Tax Credit for Raising Indonesian Tax Revenue, Int. J. Zakah, vol. 4, no. 1, pp. 77-87 (2019).

[10] Nurdin N.: Analisis 'Uqubah terhadap Muzakki yang Tidak Membayar Zakat Melalui Baitul Mal, REUSAM-Jurnal Ilmu Huk., vol. 7, no. 2, pp. 57-68 (2019).

[11] Setianingrum A. , Madjid S., and Asaari M.: Zakat As Tax Credit For Harmonize Fiscal Setting In Indonesia, J. Ekon. Pembang., vol. 16, no. 1, pp. 57-72 (2018).

[12] Klaudia S. , Riwayanti D. R., and Nisa A.: Menggali Realitas Kepatuhan wajib pajak pemilik UMKM, J. Penelit. Teor. Terap. Akunt., vol. 2, no. 1, pp. 50-64 (2017).

[13] Ascarya: Analytic Network Process (ANP): Pendekatan Baru Studi Kualitatif. Jakarta: Center for Central Banking Education and Studies, Bank Indonesia (2005).

[14] Saaty T. L. and Vargas L.: The Analytic Network Process. Pittsburgh: University of Pittsburgh.

[15] Ediraras D. T.: Akuntansi dan Kinerja UMKM, J. Ekon. Bisnis, vol. 15, no. 2, pp. 152158 (2010).

[16] Aliyah S.: Makna Pajak dan Implikasinya Dalam Bingkai Perspektif Wajib Pajak UMKM (Studi Interpretatif pada Wajib Pajak UMKM di Kabupaten Jepara), J. Din. 
Ekon. Bisnis, vol. 11, no. 1 (2014).

[17] Sari N. P. R. and Maradona A. F.: Kenapa Wajib Pajak UMKM Enggan Membayar Pajak Penghasilan?, E-Jurnal Akunt., vol. 30, no. 6, pp. 1561-1574 (2020).

[18] Cahyani L. P. G. and Noviari N.: Pengaruh Tarif Pajak, Pemahaman Perpajakan, dan Sanksi Perpajakan Terhadap Kepatuhan Wajib Pajak UMKM, E-Jurnal Akunt. Univ. Udayana, vol. 26, no. 3, pp. 1885 - 1911 (2019).

[19] Ryandono M. N. H.: Ekonomi ziswaq (Zakah, infaq, shadaqah, dan waqaf). Surabaya: IFDI dan Cenforis (2008).

[20] Mufidati K.: Peran Badan Amil Zakah dalam Memberdayakan UMKM Melalui Zakah Produktif di Kota Surabaya, J. Ilm. Mhs. FEB, vol. 5, no. 1, pp. 1-16 (2016).

[21] Kementerian Agama, Al Qur'an dan Terjemahannya. Jakarta: Kementerian Agama RI, (2020).

[22] Beik I. S.: Analisis peran zakat dalam mengurangi kemiskinan: studi kasus Dompet Dhuafa Republika, J. Pemikir. dan gagasan, vol. 2, no. 1, pp. 1-11 (2009).

[23] Firmansyah: Zakat sebagai instrumen pengentasan kemiskinan dan kesenjangan pendapatan, J. Ekon. dan Pembang., vol. 21, no. 2, pp. 179-190 (2013).

[24] Prahesti D. D. and Putri P. P.: Pemberdayaan usaha kecil dan mikro melalui dana zakat produktif, Ilmu Dakwah Acad. J. Homilet. Stud., vol. 12, no. 1, pp. 141-160, (2018).

[25] Kadir A., Hakim M. R., Syam F., and Karim M. S. A.: Pengunaan Dana Zakat Pada Korban Covid-19 Perspektif Maqashid Syariah, Al-Tafaqquh J. Islam. Law, vol. 1, no. 2, pp. 107-116 (2020).

[26] Mukhlis A. and Beik I. S.: Analisis faktor-faktor yang memengaruhi tingkat kepatuhan membayar zakat: Studi kasus Kabupaten Bogor, Al-Muzara'ah, vol. 1, no. 1, pp. 83106 (2013).

[27] Afriyandi Y.: Diskursus Pajak dan Zakah: Kontekstualisasi dan Aplikasi di Negara Muslim, As-Salam J. Stud. Huk. Islam Pendidik., vol. 3, no. 1, pp. 1-22 (2014). 